\title{
Editorial
}

\section{Why not leave it to the experts?}

\author{
International Journal of Disclosure and Governance (2011) 8, 99-102. doi:10.1057/jdg.2011.3
}

A criticism often made of academic researchers is that they are too far removed from the 'real world' to offer any useful insights. Much better, so this argument goes, to listen to practitioners who really know what is going on. Anyone who has sympathy for this point of view is not likely to be reading this journal, but if they are, recent events in the United States offers a salutary lesson in why sometimes the independence of academics is indispensable in times of controversy and raging political partisanship.

Last week in Washington DC, the Financial Crisis Inquiry Commission released its report or to be more accurate, it released three reports: one released by the majority of commissioners who were appointed by President Obama and his Democratic administration and Congress; a dissenting report by all but one of the Republican commissioners, and yet another dissent to both of the first two by the remaining Republican Commissioner, Peter Wallison, a former official in the Reagan Administration. ${ }^{1}$

The Financial Crisis Inquiry Commission was created in 2009 by Congress as a bipartisan panel that would investigate the causes of the country's financial meltdown, much as the vaunted 9/11 Commission examined the terrorist attacks on New York and the Pentagon in September 2001. But, whereas the latter report was highly praised for its careful reconstruction of those events - and was even nominated for a Pulitzer Prize for the quality of its reporting - the Financial Crisis Inquiry has been derided for failing to agree even on what caused the greatest economic calamity since the Great Depression, let alone on whether it could have been avoided and what needs to be done to prevent it from happening again.

The majority report spread blame for the crisis widely, from the Clinton and Bush Administrations to the Federal Reserve on the government side, shoddy risk management and lending practices on Wall Street and the impact of securitization on driving ever looser subprime mortgage lending. Nothing particularly exceptional in these findings, but the majority report has been highly criticized for being shallow, not going much beyond what was already known and for not following up its findings with in depth public examinations of the key characters involved. To some extent, this was inevitable given that the commission was only given a year and a budget of just US $\$ 8$ million to complete its job. That amount may seem a lot compared to what an academic researcher has to spend, but by contrast, the $9 / 11$ Commission spent $\$ 15$ million and the Starr Commission into the sexual peccadillos of President Clinton spent $\$ 47$ million. The low budget allocated to the Financial Crisis Inquiry Commission is perhaps indicative that the commission was never intended to be the freewheeling open ended examination of Wall Street that marked the similar investigation conducted by Ferdinand Pecora in the 1930s that was famous for revealing the scandals in the marketplace that gave rise to the Great Depression.

At least the majority report concluded that with appropriate regulation the crisis could have been avoided. As it states:

We conclude this financial crisis was avoidable. The crisis was the result of human action 
and inaction, not of Mother Nature or computer models gone haywire. The captains of finance and the public stewards of our financial system ignored warnings and failed to question, understand, and manage evolving risks within a system essential to the well-being of the American public. Theirs was a big miss, not a stumble. While the business cycle cannot be repealed, a crisis of this magnitude need not have occurred. To paraphrase Shakespeare, the fault lies not in the stars, but in us.

By contrast, the dissenting report by the three Republican commissioners complained that the majority report spread blame so broadly that no particular player was held responsible. As they stated: "Not everything that went wrong during the financial crisis caused the crisis, and whereas some causes were essential, others had only a minor impact. Not every regulatory change related to housing or the financial system before the crisis was a cause. The majority's almost 550-page report is more an account of bad events than a focused explanation of what happened and why. When everything is important, nothing is'. ${ }^{2}$

But, in fact, their minority report spreads the blame even more widely, claiming that the fact that the financial crisis also hit Europe implies that the problem could not be with US regulations or institutions. They state that '10 causes, global and domestic, are essential to explaining the financial and economic crisis' and it is significant that they begin this list with the credit bubble caused by the surpluses accumulated by China in the late 1990s. At some point, this history lesson leaves the impression, exactly contradicting the majority report, that the financial crisis was an act of nature that overwhelmed the best intentions of all the players.

In total contrast, the third report by Peter Wallison states that everything is the fault of the US government, particularly its policy goal of encouraging home ownership through the creation of secondary mortgage giant Fannie Mae, and the Community Reinvestment Act of 1977 that encouraged lending to population groups, such as minorities, previously discriminated against by commercial lenders. ${ }^{3}$ As Wallison states: 'I believe that the sine qua non of the financial crisis was US government housing policy, which led to the creation of 27 million subprime and other risky loans - half of all mortgages in the United States - which were ready to default as soon as the massive 1997-2007 housing bubble began to deflate. If the US government had not chosen this policy path - fostering the growth of a bubble of unprecedented size and an equally unprecedented number of weak and high risk residential mortgages - the great financial crisis of 2008 would never have occurred'. Even his fellow Republican commissioners considered this argument as nothing more than an apologia for Wall Street.

But my point here is not discuss the relative merits of these three reports, or even to criticize that there are three of them: after all, the causes of the Great Depression has long been the subject of debate, including famously between Nobel Prize winner Milton Friedman and John Maynard Keynes. But what is depressing about the outcome of this commission is that it is so nakedly partisan. It is one thing to have disagreements, quite another for that disagreement to break down along such clearly political lines.

And that is where the value of academics comes in. Disagreement is the lifeblood of academia, but to a much greater extent than in politics, or even in the marketplace, academics tend to subsume their own political biases to the facts. We may laugh at the old chestnut about the professor complaining 'why let a dirty fact ruin a beautiful theory?' but to the extent that academics aim to live by the scientific principle, they will not approach a research project with a predetermined outcome in mind.

Whatever the shortcomings of the Financial Crisis Inquiry Commission, they at least managed to accumulate a large collection of primary documents and testimony from many of the players involved, from Wall Street to 
Washington. As Jesse Eisinger of ProPublica stated: 'The commission is expected to continue releasing documents, including transcripts of interviews with bankers. Reporters are likely to find stories for months in the trove of documents, and historians will make use of the report for decades to come'. ${ }^{4}$ And this may indeed prove to be the saving grace of this exercise that it provides the raw materials for academics - and not just historians, but economists and those focusing on corporate governance - to undertake an independent and in-depth examination of the economic calamity that we all continue to live through. This journal will be among those which will provide a forum for this essential work, including in our 2011 special issue on Financial Crises and Regulatory Responses, the call for papers for which can be found on the journal web site.

Talking of the lessons from history let me end with the enduring wisdom of Ferdinand Pecora, writing in the preface to his memoir of his famous commission, which illustrates, among other things, that even if we do agree on what causes a crisis, that's not to say that we will end up doing anything better the next time around (1939):

Under the surface of the governmental regulation of the securities market, the same forces that produced the riotous speculative excesses of the 'wild bull market' of 1929 still give evidences of their existence and influence. Though repressed for the present, it cannot be doubted that, given a suitable opportunity, they would spring back into pernicious activity. Frequently we are told that this regulation has been throttling the country's prosperity. Bitterly hostile was Wall Street to the enactment of the regulatory legislation. It now looks forward to the day when it shall, as it hopes, reassume the reins of its former power.

That its leaders are eminently fitted to guide our nation, and that they would make a much better job of it than any other body of men, Wall Street does not for a moment doubt. Indeed, if you now hearken to the Oracles of The Street, you will hear now and then that the moneychangers have been much maligned. You will be told that a whole group of high-minded men, innocent of social or economic wrongdoing, were expelled from the temple because of the excesses of a few. You will be assured that they had nothing to do with the misfortunes that overtook the country in 1929-1933; that they were simply scapegoats, sacrificed on the altar of unreasoning public opinion to satisfy the wrath of a howling mob blinding seeking victims.

These disingenuous protestations are, in the crisp legal phrase, 'without merit.' The case against the money-changers does not rest upon hearsay or surmise. It is based upon a mass of evidence, given publicly and under oath before the Banking and Currency Committee of the United States Senate in 1933-1934, by The Street's mightiest and best-informed men. Their testimony is recorded in twelve thousand printed pages. It covers all the ramifications and phases of Wall Street's manifold operations.

The public, however, is sometimes forgetful. As its memory of the unhappy market collapse of 1929 becomes blurred, it may lend at least one ear to the persuasive voices of The Street subtly pleading for a return to the 'good old times.' Forgotten, perhaps, by some are the shattering revelations of the Senate Committee's investigation; forgotten the practices and ethics that The Street followed and defended when its own sway was undisputed in those good old days.

After five short years, we may now need to be reminded what Wall Street was like 
before Uncle Sam stationed a policeman at its corner, lest, in time to come, some attempt be made to abolish the post.

\section{NOTES}

1 http://www.fcic.gov/report/

2 http://c0182732.cdn1.cloudfiles.rackspace cloud.com/fcic_final_report_hennessey_ holtz-eakin_thomas_dissent.pdf

3 http://c0182732.cdn1.cloudfiles.rackspace cloud.com/fcic_final_report_wallison_ dissent.pdf
4 http://dealbook.nytimes.com/2011/02/02/ in-postcrisis-report-a-weak-light-oncomplex-transactions/?ref=business

\section{REFERENCE}

Pecora, F. (1939) Wall Street Under Oath. New York City: Simon and Shuster.

Michael Alles

Editor 